\title{
DETERMINATION OF PHYSIOLOGICAL PARAMETERS OF TILIA CORDATA MILL. IN DIFFERENT ENVIRONMENTS CULTIVATION
}

\author{
M. B.Matraimov, P. Salaš, T. Baltazár
}

Received: September 13, 2012

\begin{abstract}
MATRAIMOV, M. B., SALAŠ, P., BALTAZÁR, T.: Determination of physiological parameters of Tilla cordata Mill.in different environments cultivation. Acta univ. agric. et silvic. Mendel. Brun., 2012, LX, No. 8, pp. 155162

This experiment investigated the effect of different container design on growth and development of Small-leaved lime (Tilia cordata Mill.). Experimental plants acquired in the Netherlands were of standardized height 0.4 meters, with diameter of the root neck of 3-5 mm. To monitor the effect of different types of containers ("Air-Pot ${ }^{\text {tu }}$ " container - Bohemiaseed, s. r. o., Squared containers "Vet" - SINCO Ltd., Containers 50 Series MCI/MCC - round plastic nursery containers, "Air pot" garden bags - Arbo ${ }^{\circledR}$ Standard, Poland) on the physiological and morphological parameters of plants, three types of nursery containers were selected with open ground as control variant. Statistically significant difference between fluorescence and time of measurement was also found. In the Small-leaved lime the container type did not affect chlorophyll content or chlorophyll fluorescence (Fv/Fm); plants grown in Containers 50 Series MCI/MCC showed a lower chlorophyll content compared to plants grown in "Air-Pot " ${ }^{\text {s" } " ~ c o n t a i n e r s . ~ A s ~ r e p o r t e d ~ i n ~ l i t e r a t u r e, ~ F v / F m ~ r a t i o ~ i s ~ a ~ r e l i a b l e ~ i n d i c a t o r ~ o f ~ t h e ~}$ occurrence of environmental stresses, including water stress, on air-pot bag for several woody and herbaceous species.
\end{abstract}

Tilia cordata Mill., nursery stock quality, abiotic stressors, container production

Plants are sessile organisms that cannot escape from environmental constraints and, as a result, they have evolved numerous adaptive responses to cope with environmental stresses. Most environmental stresses share common effects and responses such as reduction in growth and photosynthesis, oxidative damage, hormonal changes, and accumulation of numerous abiotic stresses (Kacperska, 2004; Dobra et al., 2010).

Trees grown in containers develop root systems that are different from trees grown by other nursery production methods. Instead of spreading to their natural distance (Stout, 1956; Watson and Himelick, 1982) roots on shade trees are deflected up, down, or around by container walls (Harris and Gilman, 1991), and this can affect how roots grow out into landscape soils. Roots growing away from the trunk can also be deflected 180 degrees and grow back to and close to the trunk forming a root kink.
Root systems on trees planted from containers also have more constricted, circling, and kinked roots. Naturally regenerated seedlings had greater sinker root development, and possessed self grafted roots (Halter et al., 1993).

Plants grown in standard plastic containers for too long often have deformed roots that are kinked or grow along the sides or bottom of the root ball. Many variant container types have been designed to reduce the incidence of deformed roots. These options typically utilize one or more of the following: air root-pruning technology, specialized container shapes, bottomless containers, nonwoven fabrics, mechanical deflection, or chemical manipulation (Amonso et al., 2010).

Root deformation occurs even before trees root in enough to be lifted out of a container, and these can persist to cause instability many years later. Many studies on conifer seedlings show that root 
deflection in small containers can contribute to long-term growth problems after planting in the forest. Plants grown in standard black plastic containers for too long often have deformed roots which are kinked or grow along the sides or bottom of the root ball. Many variant container types were designed to reduce formation of deformed roots. These typically utilize one or more of the following: air root pruning technology, specialized container shapes, bottomless containers, woven or nonwoven fabrics, mechanical deflection or chemical manipulation (Brass et al., 1996; Marler and Willis, 1996).

When porous-walled plastic containers are used, root growth is stopped at the wall-substrate interface (Privett and Hummel, 1992): the tip roots reach the container wall hole and are desiccated. As a result of the loss of root apical dominance, more fine roots develop in the inner part of the root ball, allowing a more even root system (Marler and Willis, 1996). Air-pruning technology can be combined with techanical deflection by including vertical ribs on the interior container surfaces (Rune, 2003). Thus, the objective of this experiment was to evaluate the effect of four different containers and also as a control version open ground on plant growth and root architecture of Tilia cordata Mill. To provide further insight into the effect of container shape on plant stress, chlorophyll content and chlorophyll fluorescence were also studied.

\section{MATERIALS AND METHODS}

The experiment was established at a multipurpose scientific experimental workplace on plots of the Faculty of Horticulture in Lednice in April 2012.

Small-leaved lime (Tilia cordata Mill.) was selected as the object of the study, which is one of the species with relatively simple technology that is growing with the increasing demand for water and leaf area large enough to accurately measure the parameters. Experimental plants acquired in the Netherlands (Importer of plants in the Czech Republic, the company ARBOEKO, s.r.o., Obříství) have been of standardized height of 0.4 meters, with diameter of the root neck of $3-5 \mathrm{~mm}$. To monitor the effect of different types of containers („Air-Pot ${ }^{\mathrm{mu}}$ c container - Bohemiaseed, s.r.o., Squared containers "Vet" - SINCO Ltd., Containers 50 Series MCI/MCC round plastic nursery containers, "Air pot" garden bags - Arbo ${ }^{\circledR}$ Standard, Poland) on the physiological and morphological parameters of plants, three types of nursery containers were selected and the control variant was open ground. All used garden containers had the same volume - 5L. In the experiment, each variant used 50 pieces of planting material, repeated experiments were doubled. Used planting technology was traditional. Control plants were grown in naked soil and planted in the conventional nursery manner on an open site.

The substrate used was peat mixture RKS II from manufacturer AGRO CS, a. s., Česká Skalice.
Chemical and physical characteristics of the substrate: $\mathrm{pH}$ 5.5-7.0; N 250-350 mg.1L.; $\mathrm{P}_{2} \mathrm{O}_{5}$ 200250 mg.1L.; $\mathrm{K}_{2} \mathrm{O} 300-400 \mathrm{mg}$. 1L.

The irrigation system was automatic; containers had sensors for measuring humidity and temperature of the substrate. Temperature for automatic irrigation was installed and set to $25^{\circ} \mathrm{C}$ degrees.

During the growing season physiological and morphological parameters of plants were measured. Physiological measurements were done from May to August. Specific equipment used included: to determine the content of chlorophyll in leaf - Chlorophyll Content Meter (CCM-200) identification and assessment of plant stress physiology and the general study of plants, measurements of chlorophyll fluorescence using Chlorophyll Fluorometer OS-30. Before planting, the plants were measured upon their morphological parameters: height of plants, root system length and diameter of root neck.

The data processing was carried out in Microsoft Office Excel 2010 and all statistic analyses were performed using freely available statistic programme R version 2.15.1. (R Development Core Team 2012), for editing R scripts Tinn-R code editor was used (Faria, 2011).

The aim of this data analysis was to compare the group means between control and variants. For this purpose one-way analysis of variance (ANOVA) type I (sequential) sum of squares was used. Treatment contrast was used to estimate factor level means and to determine significance difference between control and variants (at 0.05 significance level). To compare the group means between times of measurements, one-way ANOVA type I (sequential) sum of squares was used as well. Treatment contrast was also used to estimate factor level means. To determine the difference between times of measurement, Fisher's least significant difference (LSD) test from "agricolae" package (Mendiburu, 2010) and Dunnett-Tukey-Kramer pair-wise multiple comparison test from package "DTK" (Lau 2011) was used. $95 \%$ confidence intervals (CI) for the mean were also calculated in all cases.

After the analysis, the assumptions of ANOVA were checked. To test normality (at 0.01significance level) Shapiro-Wilk normality test and Cramervon Mises test from "nortest" package (Gross et. al., 2011) were used. To test the homoscedasticity (also at significance 0.01 level) Bartlett's test and Levene's test from "car" package (Fox and Weisberg 2011) were used. Besides, the assumption checking was also performed by diagnostic plots. For this purpose the following diagnostic plot was used: plot of residuals versus fitted values, normal Q-Q plot of standardized residuals, scale-location plot, plot of residuals versus leverage, Cook's distance plot and plot of Cook's distance versus leverage. 


\section{RESULTS AND DISCUSSION}

In some cases the assumptions of one-way ANOVA were not satiated completely (normality, homoscedasticity), therefore the data analysis was also repeated with non-parametric statistical methods. For this purpose Kruskal-Wallis chisquare test was used. Two-tailed comparison (variants vs. control) and multiple comparisons (between measurements) were used to detect the difference after Kruskal Wallis chi-square test. For this purpose "pgirmess" the package (Giraudoux, 2012) was used.

\section{The average value of $\mathrm{CCl}$ with $\mathrm{Cl} 95 \%$}

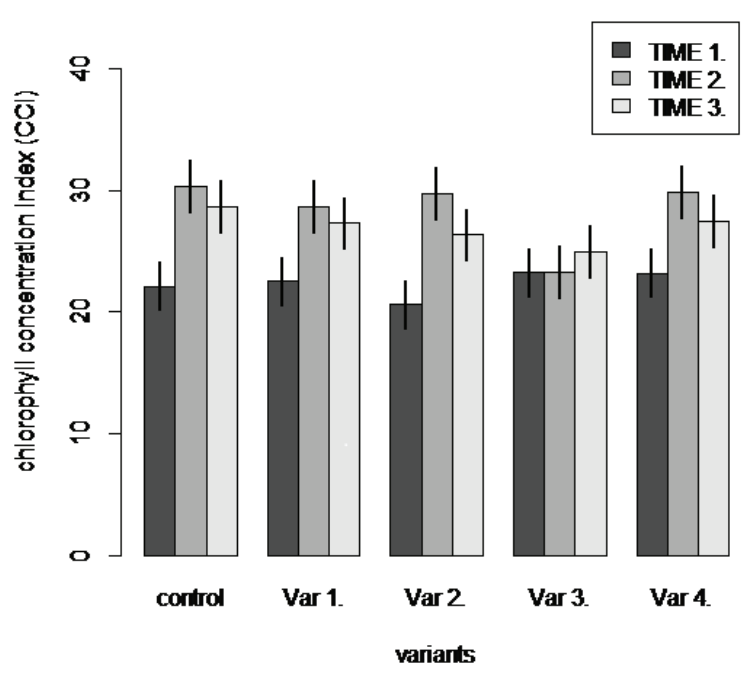

1: The index values of chlorophyll (CCI) specific variants of three measurement conditions
Due to our results we can conclude that in case of chlorophyll concentration index (CCI) there are no statistic significance differences between the control and variants in case of $1^{\text {st }}$ measurement $\left(\mathrm{F}_{4,195}=1.14, \mathrm{p}=0.34 ; \chi^{2}=5.01, \mathrm{df}=4, \mathrm{p}=0.29, \mathrm{n}=40\right.$ in each group), but there are statistically significant differences in case of $2^{\text {nd }}$ measurement $\left(\mathrm{F}_{4105}=7.13\right.$, $\mathrm{p}<0.001 ; \chi^{2}=23.44, \mathrm{df}=4, \mathrm{p}<0.001, \mathrm{n}=40$ in each group) and also no statistically significant difference was found in case of $3^{\text {rd }}$ measurement $\left(\mathrm{F}_{4.195}=1.67\right.$, $\mathrm{p}=0.16 ; \chi^{2}=6.03, \mathrm{df}=4, \mathrm{p}=0.20, \mathrm{n}=40$ in each group).

Statistically significant difference between chlorophyll content index (CCI) and time of measurement $\left(\mathrm{F}_{2,597}=42.54, \mathrm{p}<0.001 ; \chi^{2}=78.91\right.$, $\mathrm{df}=2, \mathrm{p}<0.001, \mathrm{n}=200$ in each group). Statistically significant difference was found between $1^{\text {st }}$ and $2^{\text {nd }}$ measurement (Tukey HSD: $\mathrm{p}<0.001$; LSD: $\mathrm{p}<0.001$; Multiple comparison test after Kruskal-Wallis: significance difference) respectively between $1^{\text {st }}$ and $3^{\text {rd }}$ measurement (Tukey HSD: $\mathrm{p}<0.001$; LSD: $\mathrm{p}<0.001$; Multiple comparison test after KruskalWallis: significant difference). There is no difference between $2^{\text {nd }}$ and $3^{\text {rd }}$ measurement (Tukey HSD: $\mathrm{p}=0.04$; LSD: $\mathrm{p}=0.10$; Multiple comparison test after Kruskal-Wallis: no significant difference). The average CCI value of $1^{\text {st }}$ measurement was 22.32 (95\% CI [21.37, 23.27]), in $2^{\text {nd }}$ measurement it was 28.35 (95\% CI [27.40, 29.30]) and in $3^{\text {rd }}$ measurement it was 26.94 (95\% CI [25.99, 27.89]).

In case of fluorescence, significant difference was found between control and variants: $1^{\text {st }}$ measurement $\left(\mathrm{F}_{4,195}=10.18, \mathrm{p}<0.001 ; \chi^{2}=34.49\right.$, $\mathrm{df}=4, \mathrm{p}<0.001, \mathrm{n}=40$ in each group), $2^{\text {nd }}$ measurement $\left(\mathrm{F}_{4,195}=9.00, \mathrm{p}<0.001 ; \chi^{2}=41.71, \mathrm{df}=4\right.$, $\mathrm{p}<0.001, \mathrm{n}=40$ in each group), and $3^{\text {rd }}$ measurement $\left(\mathrm{F}_{4,195}=4.69, \mathrm{p}=0.0012 ; \chi^{2}=15.84, \mathrm{df}=4, \mathrm{p}=0.0032\right.$, $\mathrm{n}=40$ in each group).

I: The average value of chlorophyll concentration index (CCI) with CI 95\% and significant difference to "control"

\begin{tabular}{|c|c|c|c|c|c|}
\hline Factor levels & $\begin{array}{c}\text { Time of } \\
\text { measurement }\end{array}$ & Mean & CI (95\%) & $\begin{array}{l}\text { Result of treatment } \\
\text { contrast (P-value) }\end{array}$ & $\begin{array}{l}\text { Significance results } \\
\text { after Kruskal Wallis }\end{array}$ \\
\hline \multirow{3}{*}{ Control (open soil) } & 1 & 22.10 & $20.12-24.08$ & - & - \\
\hline & 2 & 30.27 & $28.12-32.42$ & - & - \\
\hline & 3 & 28.67 & $26.55-30.78$ & - & - \\
\hline \multirow{3}{*}{ "Air-Pot" ${ }^{\mathrm{"} "}$ " } & 1 & 22.49 & $20.51-24.47$ & 0.79 & FALSE \\
\hline & 2 & 28.63 & $26.48-30.77$ & 0.29 & FALSE \\
\hline & 3 & 27.30 & $25.18-29.42$ & 0.37 & FALSE \\
\hline \multirow{3}{*}{ Square containers } & 1 & 20.61 & $18.63-22.58$ & 0.29 & FALSE \\
\hline & 2 & 29.71 & $27.56-31.86$ & 0.72 & FALSE \\
\hline & 3 & 26.32 & $24.20-28.43$ & 0.12 & FALSE \\
\hline \multirow{3}{*}{$\begin{array}{l}\text { Containers } 50 \text { Series } \\
\text { MCI/MCC }\end{array}$} & 1 & 23.24 & $21.26-25.22$ & 0.42 & FALSE \\
\hline & 2 & 23.26 & $21.11-25.41$ & $\mathrm{p}<0.001$ & TRUE \\
\hline & 3 & 24.96 & $22.84-27.07$ & 0.02 & TRUE \\
\hline \multirow{3}{*}{ Air-bag pot } & 1 & 23.17 & $21.19-25.15$ & 0.45 & FALSE \\
\hline & 2 & 29.89 & $27.74-32.04$ & 0.81 & FALSE \\
\hline & 3 & 27.46 & $25.34-29.58$ & 0.43 & FALSE \\
\hline
\end{tabular}


The average value of fluorescence with $\mathrm{CI} 95 \%$

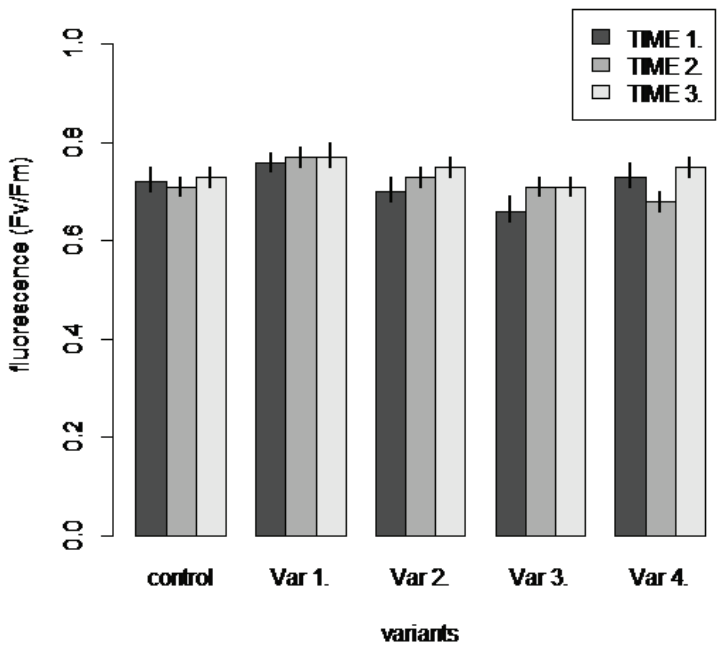

2: The values of chlorophyll fluorescence Fv / Fm of the options measured on the three dates

Statistically significant difference was also found between fluorescence and time of measurement $\left(\mathrm{F}_{2,597}=6.90, \mathrm{p}=0.0011 ; \chi^{2}=14.23, \mathrm{df}=2, \mathrm{p}<0.001\right.$, $\mathrm{n}=200$ in each group). The statistically significant difference was found between $1^{\text {st }}$ and $3^{\text {rd }}$ measurement (Tukey HSD: $\mathrm{p}=0.002$; LSD: $\mathrm{p}<0.001$; Multiple comparison test after Kruskal-Wallis: significant difference) respectively between $2^{\text {nd }}$ and $3^{\text {rd }}$ measurement (Tukey HSD: $p=0.01$; LSD: $\mathrm{p}=0.004$; Multiple comparison test after KruskalWallis: significant difference). There is no difference between $1^{\text {st }}$ and $2^{\text {nd }}$ measurement (Tukey HSD: $\mathrm{p}=0.85$; LSD: $\mathrm{p}=0.59$; Multiple comparison test after Kruskal-Wallis: no significant difference). The average fluorescence value of $1^{\text {st }}$ measurement was
0.72 (95\% CI [0.71, 0.73]), 2 $2^{\text {nd }}$ measurement was 0.72 (95\% CI [0.71, 0.73]) and $3^{\text {rd }}$ measurement was 0.74 (95\% CI $[0.73,0.75])$.

For height of plants there is no statistically significant difference between control and variants in case of $1^{\text {st }}$ measurement $\left(\mathrm{F}_{4,195}=0.162, \mathrm{p}=0.96\right.$; $\chi^{2}=0.42, \mathrm{df}=4, \mathrm{p}=0.98, \mathrm{n}=40$ in each group). There are statistically significant differences in case of $2^{\text {nd }}$ measurement $\left(\mathrm{F}_{4,195}=23.54, \mathrm{p}<0.001 ; \chi^{2}=57.65\right.$, $\mathrm{df}=4, \mathrm{p}<0.001, \mathrm{n}=40$ in each group) and in case of $3^{\text {rd }}$ measurement $\left(\mathrm{F}_{4.195}=40.84, \mathrm{p}<0.001 ; \chi^{2}=88.95\right.$, $\mathrm{df}=4, \mathrm{p}<0.001, \mathrm{n}=40$ in each group).

Statistically significant difference was also found between height of plants and time of measurement $\left(\mathrm{F}_{2,597}=665.22, \mathrm{p}<0.001 ; \chi^{2}=467.81\right.$, $\mathrm{df}=2, \mathrm{p}<0.001, \mathrm{n}=200$ in each group). In all cases statistical significance was found: between $1^{\text {st }}$ and $2^{\text {nd }}$ measurement (Tukey HSD: $p<0.001$ LSD: $\mathrm{p}<0.001$; Multiple comparison test after KruskalWallis: significant difference), between $1^{\text {st }}$ and $3^{\text {rd }}$ measurement (Tukey HSD: p < 0.001; LSD: < 0.001; Multiple comparison test after Kruskal-Wallis: significant difference) respectively $2^{\text {nd }}$ and $3^{\text {rd }}$ measurement (Tukey HSD: p > 0.001; LSD: < 0.001; Multiple comparison test after Kruskal-Wallis: significant difference). The average height of plant was, in case of $1^{\text {st }}$ measurement 0.51 (95\% CI [0.48, $0.55]$ ), in case of $2^{\text {nd }}$ measurement 0.86 (95\% CI [0.83, $0.89]$ ) and in case of $3^{\text {rd }}$ measurement 1.39 (95\% CI $[1.36,1.42])$.

The results of this study suggest that the container typology has an influence on physiological and morphological confirmation in the tested plant. Our studies show that types of containers in which the selected plants grow are important for the growth and development of plants in the nursery. The results that we can conclude are that in case of chlorophyll concentration index (CCI) there are no statistically significant difference between control

II: The average value of fluorescence with CI 95\% and significant difference to "control"

\begin{tabular}{l|ccccc}
\hline \multicolumn{1}{c}{ Factor levels } & $\begin{array}{c}\text { Time of } \\
\text { measure-ment }\end{array}$ & Mean & CI (95\%) & $\begin{array}{c}\text { Result of treatment } \\
\text { contrast (P-value) }\end{array}$ & $\begin{array}{c}\text { Significance results } \\
\text { after Kruskal Wallis }\end{array}$ \\
\hline & 1 & 0.72 & $0.70-0.75$ & - & - \\
Control (open soil) & 2 & 0.71 & $0.69-0.73$ & - & - \\
& 3 & 0.73 & $0.71-0.75$ & - & FALSE \\
\hline "Air-Pot" $"$ " & 1 & 0.76 & $0.74-0.78$ & 0.04 & TRUE \\
containers & 2 & 0.77 & $0.75-0.79$ & $<0.001$ & FALSE \\
\hline & 3 & 0.77 & $0.75-0.80$ & 0.008 & FALSE \\
\hline Square containers & 1 & 0.70 & $0.68-0.73$ & 0.17 & FALSE \\
& 2 & 0.73 & $0.71-0.75$ & 0.13 & FALSE \\
\hline \multirow{2}{*}{ Containers 50 Series } & 3 & 0.75 & $0.73-0.77$ & 0.19 & TRUE \\
MCI/MCC & 1 & 0.66 & $0.64-0.69$ & $<0.001$ & FALSE \\
\hline & 2 & 0.71 & $0.69-0.73$ & 0.81 & FALSE \\
\hline Air-bag pot & 3 & 0.71 & $0.69-0.73$ & 0.17 & FALSE \\
& 1 & 0.73 & $0.71-0.76$ & 0.56 & FALSE \\
\hline
\end{tabular}


III: The average value of plants with CI $95 \%$ and significant difference to "control"

\begin{tabular}{|c|c|c|c|c|c|}
\hline Factor levels & $\begin{array}{c}\text { Time of } \\
\text { measure-ment }\end{array}$ & Mean & CI (95\%) & $\begin{array}{l}\text { Result of treatment } \\
\text { contrast (P-value) }\end{array}$ & $\begin{array}{l}\text { Significant results } \\
\text { after Kruskal Wallis }\end{array}$ \\
\hline \multirow{3}{*}{ Control (open soil) } & 1 & 0.51 & $0.48-0.54$ & - & - \\
\hline & 2 & 0.71 & $0.66-0.77$ & - & - \\
\hline & 3 & 0.97 & $0.89-1.05$ & - & - \\
\hline \multirow{3}{*}{$\begin{array}{l}\text { "Air-Pot" }{ }^{\mathrm{n} "} \\
\text { containers }\end{array}$} & 1 & 0.52 & $0.49-0.55$ & 0.64 & FALSE \\
\hline & 2 & 1.10 & $1.02-1.13$ & $<0.001$ & TRUE \\
\hline & 3 & 1.43 & $1.35-1.51$ & $<0.001$ & TRUE \\
\hline \multirow{3}{*}{ Square containers } & 1 & 0.51 & $0.48-0.54$ & 0.92 & FALSE \\
\hline & 2 & 0.82 & $0.77-0.88$ & 0.007 & TRUE \\
\hline & 3 & 1.35 & $1.26-1.43$ & $<0.001$ & TRUE \\
\hline \multirow{3}{*}{$\begin{array}{l}\text { Containers } 50 \text { Series } \\
\text { MCI/MCC }\end{array}$} & 1 & 0.51 & $0.48-0.54$ & 0.83 & FALSE \\
\hline & 2 & 0.81 & $0.75-0.86$ & 0.02 & TRUE \\
\hline & 3 & 1.65 & $1.57-1.73$ & $<0.001$ & TRUE \\
\hline \multirow{3}{*}{ Air-bag pot } & 1 & 0.52 & $0.49-0.55$ & 0.76 & FALSE \\
\hline & 2 & 0.88 & $0.82-0.93$ & $<0.001$ & TRUE \\
\hline & 3 & 1.55 & $1.47-1.63$ & $<0.001$ & TRUE \\
\hline
\end{tabular}

The average value of plants with $\mathrm{Cl} 95 \%$

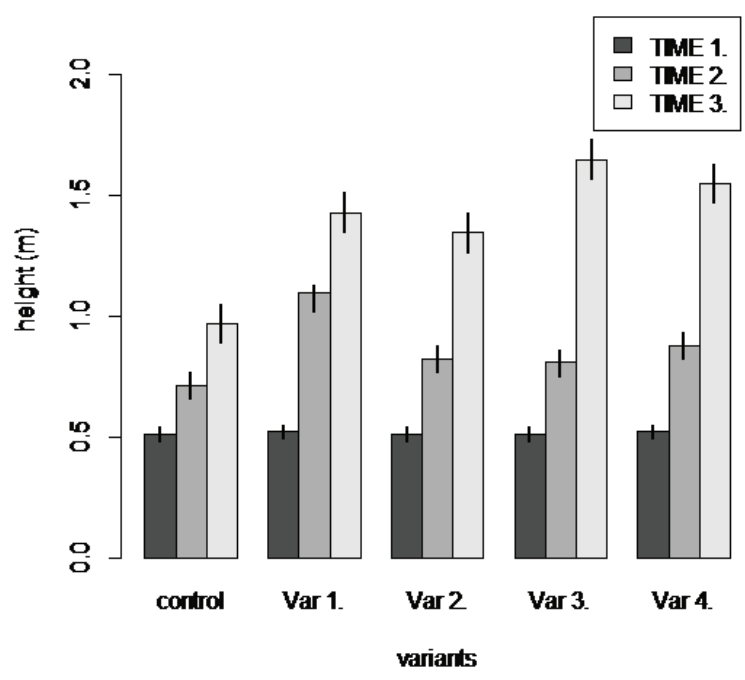

3: Mean values of the changes in plant height on three dates of measurement

and variants but there are statistically significant differences in case of two measurements (Tab. I). Statistically significant difference was found also between fluorescence and time of measurement. In the Small-leaved lime, container type did not affect chlorophyll content or chlorophyll fluorescence (Fv/Fm), whereas plants grown in Containers 50 Series MCI/MCC showed a lower chlorophyll content compared to plants grown in "Air-Pot" containers (Tab. II). As reported in the literature, Fv/Fm ratio is a reliable indicator of the occurrence of environmental stresses, including water stress, on air-pot bag for several woody and herbaceous species (Angelopulos et al., 1996; Lazar, 2006; Percival et al., 2006; Maxwell and Johnson 2000; Sloup and Salaš, 2010). In terms of individual observations there were no statistically significant differences in the total height of plants between variants and cultivation technologies.

\section{CONCLUSION}

The most important result of the present work is the increased understanding of the effect the influence of nursery containers for plant growth and development, and to obtain a high-quality nursery material. It is well known that in containerized seedlings root deformation is an effect of a poor container design (Hueltén and Jansson, 1978). Morphological and physiological data of this study have shown good results the plants that were planted in the "Air-Pot " containers. The result obtained in this study can be a useful tool to improve the quality of the root system in containerized plant production since tree survival and growth after out planting are directly related to its root morphology. As written above, at the end of the growing season, the study will be made analysis defect root system of plants, which were planted in different types of nursery containers.

\section{SUMMARY}

To improve the quality of the plant material in the nursery one should always look for new solutions for optimal growth and development of plants. The root system is one of the most sensitive organs of the plant and it determines the quality of the planting material. Studies of the effect of nursery 
containers on the physiological and morphological parameters of the plant will contribute to improvement in the quality of nursery plants. Thus, the objective of this experiment was to evaluate the effect of four different containers (and open ground as control version) on plant growth and root architecture of Tilia cordata Mill. To provide further insight into the effect of container shape on plant stress, chlorophyll content and chlorophyll fluorescence were also studied. The experiment was established at a multipurpose scientific experimental workplace on plots of the Faculty of Horticulture in Lednice in April 2012. To monitor the effect of different types of containers („Air-Pot ${ }^{\mathrm{Tm} w}$ container Bohemiaseed, s.r.o., Squared containers "Vet" - SINCO Ltd., Containers 50 Series MCI/MCC - round plastic nursery containers, "Air pot" garden bags - Arbo Standard, Poland) on the physiological and morphological parameters of plants four types of nursery containers were used with open ground as the control variant. The container type did not affect chlorophyll content or chlorophyll fluorescence (Fv/Fm), whereas plants grown in Containers 50 Series MCI/MCC showed lower chlorophyll content

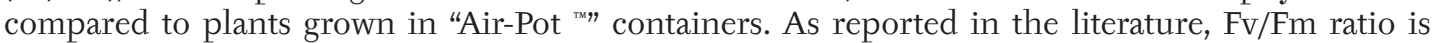
a reliable indicator of the occurrence of environmental stresses, including water stress, on air-pot bag for several woody and herbaceous species. The second stage of the study of the influence of different types of nursery containers on growth of plants and morphology of root system will be carried out at the end of the growing season (September 2012).

\section{Acknowledgement}

This publication was supported by Project No. 3/2012/591 provided by the Internal Grant Agency of MENDELU Brno.

\section{REFERENCES}

ANGELOPULOS, K.,DICHIO,B. andXILOYANNIS, C., 1996: Inhibition of photosynthesis in olive trees (Olea europaea L.) during water stress and rewatering. J. Expt. Bot. 47: 1093-1100.

AMONSO, G., FRANDI, P. and PIATTI R., 2010: Effect of container design on plant growth and root deformation of little-leaf lime and field elm. HortScience 45(12): 1824-1829.

BALISKY, A. C. et al., 1995: Seedling roots and forest floor: Misplaced and neglected aspects of British Columbia's reforestation effort. For. Chron. 71: 9-65.

BRASS, T. J. et al., 1996: Styrene-lined and coppercoated containers affect production and landscape establishment of red maple. HortScience 31: $353-$ 356.

DOBRA, J. et al., 2010: Comparison of hormonal responses to heat, drought and combined stress in tobacco plants with elevated proline contents. Journal of Plant Physiology 167, 1360-1370.

FARIA, J. C., 2011: Resources of Tinn-R GUI/Editor for R Environment.UESC, Ilheus, Brasil.

FOX, J. and WEISBERG, S., 2011: An \{R\} Companion to Applied Regression, Second Edition. Thousand Oaks CA: Sage. URL: http://socserv.socsci. mcmaster.ca/jfox/Books/Companion.

GIRAUDOUX, P., 2012: Pgirmess: Data analysis in ecology. R package version 1.5.4. URL:http:// CRAN.R-project.org/package=pgirmess .

GROSS et al., 2012: Nortest: Tests for Normality. $\mathrm{R}$ package version 1.0-2. URL:http://CRAN.Rproject.org/package=nortest.

HARRIS, J. R. and GILMAN, E. F., 1991: Production system affects growth and root regeneration of Leyland cypress, laurel oak and slash pine. J. Arboriculture. 17: 64-69.
HALTER, M. R. et al., 1993: Growth reduction and root deformation of containerized lodgepole pine saplings 11 years after planting. For. Ecol. Manag. 56: 131-146.

HULTEN, H. and JANSSON, K. Å., 1978: Stability and root deformation of pine plants (Pinus sylvestris). Royal College of For., Dept. of Reforest. Rep. 93: 84.

KACPERSKA, A., 2004: Sensor types in signal transduction pathways in plant cells responding to abiotic stressors: do they depend on stress intensity? Physiologia Plantarum 122, 159-168.

LAZAR, D., 2006: The polyphasic chlorophyll a fluorescence rise measured under high intensity of exciting light. Funct. Plant Biol. 33: 9-30.

LAU, M. K., 2011: DTK: Dunnett-Tukey-Kramer Pairwise Multiple Comparison Test Adjusted for Unequal Variances and Unequal Sample Sizes. R package version 3.1. URL:http://CRAN.R-project. org/package=DTK.

MARLER, T. and WILLIS, D., 1996: Chemical or air root pruning containers improve carambola, longam, and mango seedling root morphology and initial root growth after planting. J. Environ. Hort. 14: 47-49.

MAXWELL, K. and JOHNSON, G., 2000: Chlorophyll fluorescence-a practical guide. J. Expt. Bot. 51: 659-668.

PERCIVAL, G., KEARY I. and NOVIS, K., 2008: The potential of a chlorophyll content SPAD meter to quantify nutrient stress in foliar tissue of sycamore (Acer pseudoplatanus), english oak (Quercus robur), and european beech (Fagus sylvatica). Arboriculture \& Urban Forestry 34: 89-100.

PRIVETT, D. and HUMMEL, R., 1992: Root and shoot growth of 'Coral Beauty' cotoneaster and Leyland cypress produced in porous and nonporous containers. J. Environ. Hort. 10: 133-136. 
RUNE, G., 2003: Slits in container wall improve root structure and stem straightness of out planted Scots pine seedlings. Silva Fennica 37: 333-342.

SLOUP, J. and SALAŠ, P., 2010: Effect of soil conditioners on the quality of nursery production. Acta Hort. (ISHS) 885: 355-360.
STOUT, B. B., 1956: Studies of the root systems of deciduous trees. Black For. Bul. 15, pp. 45.

WATSON, G. W. and HIMELICK, E. B., 1982: Root distribution of nursery trees and its relationship to transplanting. J. Arboriculture. 8: 305-310. 
